\title{
Potential of Thermal Energy Storage Using Coconut Oil for Air Temperature Control
}

\author{
Surjamanto Wonorahardjo ${ }^{1, *}$, Inge Magdalena Sutjahja ${ }^{2}$, Daniel Kurnia ${ }^{2}$, Zulfikar Fahmi ${ }^{2}$ \\ and Widya Arisya Putri ${ }^{2}$ \\ 1 Building Technology Research Group, SAPPK, Institut Teknologi Bandung, Jl. Ganesha No. 10, \\ Bandung 40132, Indonesia \\ 2 Physics Department, FMIPA, Institut Teknologi Bandung, Jl. Ganesha No. 10, Bandung 40132, Indonesia; \\ inge@fi.itb.ac.id (I.M.S.); daniel@fi.itb.ac.id (D.K.); zulfikarfahmi01@gmail.com (Z.F.); \\ widyaarisya@gmail.com (W.A.P.) \\ * Correspondence: titus@ar.itb.ac.id; Tel.: +62-222-504-962
}

Received: 17 June 2018; Accepted: 20 July 2018; Published: 24 July 2018

\begin{abstract}
The role of thermal mass in indoor air-cooling during the day is a common area of study, which is particularly relevant for an era characterized by energy crises. Thermal energy storage (TES) technologies for application in rooms and buildings are not well developed. This study focuses on the use of coconut oil (co_oil) as a temperature control agent for room air conditioning systems in tropical countries such as Indonesia, given its capability to store large amounts of heat at temperatures around its melting point. Heat exchange studies between co_oil and the air environment were performed by considering three factors: Temperature difference between co_oil and the air environment, the heat absorption behavior and the release of co_oil, and the mass of co_oil required to have a significant effect. The co_oil cell sizes were formulated as responses to natural day and night air temperature profiles, while the performance of the co_oil mass for decreasing room air temperature was predicted using a thermal chamber.
\end{abstract}

Keywords: thermal energy storage (TES); temperature control agents; coconut oil; solid-liquid phase transition

\section{Introduction}

The application of indoor air conditioning systems is highly desirable in tropical countries like Indonesia. Locally- and centrally-controlled air conditioners (ACs) are installed in most buildings, including private houses, to provide cool temperatures for comfortable living and working conditions. The operation of these facilities inevitably brings about significant increases in energy consumption. Data released by the Japan International Cooperation Agency (JICA) in 2015 [1] show that AC systems for buildings in large Indonesian cities, such as Jakarta, Bandung, and Makassar are responsible for the largest proportion of electrical energy consumption (53.5\%), followed by lighting (24\%) and other electrical equipment (22.5\%). The temperature management strategy of day and night thermal balancing has been introduced as a passive strategy for thermal environment conditioning, which requires no additional energy for implementation [2]. This strategy requires a thermal energy storage (TES) mechanism using a TES medium [3]. It has been reported to reduce indoor air temperature fluctuations and shifting the peak temperatures in buildings [4-7]. Heat exchanges between the thermal masses and their surroundings primarily take place by conductive and convective processes, which largely depend on temperature differences between the surrounding air and the thermal storage mass, as well as the thermal conductivity of the mass container. A thermal mass substance with a low 
melting point and large heat capacity could facilitate the heat exchange process and effectively act as a temperature stabilizer for the room [8].

Commonly used building materials in cities, such as bricks, concrete, ceramic, and glass function as thermal masses that may influence the air temperature and the fluctuation throughout the day, particularly between day and night. These relatively large materials, excluding their structural roles, are commonly used as a building envelope for resisting heat transfer from outside to the inside of the building, and are also used as a building heat reservoir [9]. Brick is one of the most popular building materials in Indonesia due to its durability under the hot and humid environment; however, the abilities of these materials in adjusting room temperature are limited, and often do not have significant roles in cooling rooms or buildings during the daytime. These materials do not meet the basic criteria mentioned above for thermal storage masses.

The uncomfortable thermal environment conditions that generally occur in buildings in humid tropics are: (1) Quite wide daily fluctuations of air temperature in dry seasons; and (2) hot humid nighttime during the rainy season [10]. In the dry seasons, the solar radiation is very large during the daytime and in general, the roof cover is not able to decrease the solar radiation. Conversely, at night the air temperature drops beyond the comfort limit. The eastern wall acts as a thermal mass [9] and gives a comforting-warming effect during the night. It is the opposite in the rainy season, the hot humid nighttime becomes worse if the eastern wall gains an intense morning solar radiation because it stores a lot of heat and releases it back in the hot night [9]. Application of TES in a building is to generate a thermal balance between day and night in dry and rainy seasons [11]. In addition, TES applications have flexibilities in indoor settings for room features (e.g., as room partitions or a drop ceiling, etc.) [12-16].

It is necessary to develop technologies of building components integrating TES such as wallboard [17], gypsum board [18], or reinforced concrete structures [19] to improve indoor air temperatures (i.e., shifting peak temperatures and decreasing their intensity) $[11,20]$. This passive strategy requires considerable material processing at a significant cost, and in some cases, the chemical dopants leave some environmental problems in recycling and treatment of the materials after use.

The complexity of the passive technologies is on the method to be fit with several seasons and different weather conditions. Experts highlight some performances of TES (i.e., heat flux reduction through building envelope [21], controlling storage period [22], and storage capacity [22-26]). Some important aspects that controls the storage periods are the melting and solidification temperatures, as well as the thermal conductivity value. A number of studies that deal with melting temperature and solidification show methods of choosing a right phase change material (PCM) for the desired working temperature [25]. In contrast to the aspect of the storage period, many experts add appropriate dopant material to improve the thermal conductivity [27] such as graphite [28] or metal nanoparticles [29]. The interventions on the thermal conductivity value affect the charging-discharging rates as well [30]. The night temperature value is not always fit with the required solidification temperature of the PCM, so that the discharging process does not occur completely, especially in weather that tends to be cloudy and warm. Weather conditions of day and night are not always the same, so that loads of cooling and heating are not always balanced. The solidification process becomes an important aspect in which the role of PCM cell size and solidification agent are important, so that solidification activation, such as dew point convective cooling, will be useful [31].

In this paper, we demonstrate the performance of coconut oil (co_oil) as an effective thermal storage mass in Bandung, Indonesia, in comparison with traditional building materials. Thermal energy storage using co_oil utilizes its low-melting temperature, around $26^{\circ} \mathrm{C}$, with solid and liquid specific heats of $c_{p, s}=3.23 \mathrm{~kJ} / \mathrm{kg} \cdot \mathrm{K}$ and $c_{p, l}=2.35 \mathrm{~kJ} / \mathrm{kg} \cdot \mathrm{K}$ [32], and its relatively large heat of fusion $(\mathrm{h}=70-100 \mathrm{~kJ} / \mathrm{kg})[32,33]$. Reviews on numerous PCM as latent TES materials, which melt and solidify at a wide range of temperatures, for various applications has been published by Sharma et al. [34], Zalba et al. [35], Pomianowski [36], and Du [37]. Several researchers have reported on the potential of co_oil use in active or passive TES systems for both heating and cooling of ambient air. As an active 
medium, co_oil can be used as a secondary refrigerant $[11,38]$ and as an agent for reducing the initial temperature of heat transfer fluid in an air conditioning machine [39]. As a passive medium, co_oil is used to control the room air temperature, as Mettawee and Ead [40] reported on its application in Sudan. Despite its abundant availability at a relatively low cost, as well as being human and environmentally friendly [41], the use of co_oil is impeded by its low thermal conductivity. Coconut oil as organic PCM has relatively long lifetime since it is thermally stable like many other organic PCMs [42], and it has no phase separation which commonly occurs in inorganic salt hydrate PCM [43].

The aim of this work is to address the above problems by proposing a passive strategy for the application of co_oil cells as a temperature control agent in Indonesia. A study focusing on the thermal characteristics of local co_oil without any dopant, and the heat exchange performances of a variety of cell geometries and sizes, is conducted. The results could be used to predict the minimum amount of co_oil required to achieve effective temperature maintenance of a typical Indonesian living room.

Several studies on the stability of coconut oil have demonstrated that, in general, co_oil deterioration could be caused by oxidation and microorganisms [44-49]. Coconut oil stored in a dark bottle at room temperature $\left(25^{\circ} \mathrm{C}\right)$ possesses better oxidative properties than other vegetable oils, such as sunflower and sesame oil, as it contains saturated fatty acids [44,45]. Experiments have demonstrated that coconut oil quality is not affected during 12 months of storage [46]. The relatively small moisture content $(<1 \%)$, low iodine value $(13.18 \pm 0.22)$, and low BOD (biochemical oxygen demands, $500 \mathrm{mg} / \mathrm{L}$ ) of the co_oil show that it has relatively great biostability and extremely resistant to the development of rancidity due to small content of unsaturated fatty acid [47,48]. We note finally that the temperature interval for the charging and discharging processes of co_oil as an indoor room thermal mass is around room temperature so that the material will not experience chemical degradation as long as it is stored in a closed and clean container. As a comparison, virgin coconut oil (VCO) that was heated at $190^{\circ} \mathrm{C}$ six times and stored in a closed tube without exposure to light for 40 days shows less oxidation due to its saturated fatty acids [49]. Thus, it can be assumed that with the chemical stability of co_oil, the daily charging and discharging processes will not affect its thermal properties considerably.

\section{Materials and Methods}

The experiments involved a commercial co_oil brand in Indonesia. The temperature was measured in a non-air conditioned room using the calibrated temperature sensors of T-type thermocouple from Applent with an accuracy of $0.2 \%+1{ }^{\circ} \mathrm{C}$. To predict the effectiveness of co_oil cells in controlling air temperature, we studied three factors: (1) Temperature difference between co_oil $(T)$ and the air $\left(T_{a}\right)$; (2) the behavior of heat absorption and release of co_oil; and (3) mass of co_oil required to significantly influence the air environment.

The heat exchange between the environment and co_oil occurs when the air temperature differs from the co_oil temperature. The heat transport mechanism involves conduction and convection dominantly. Heat transfer occurs by conduction when co_oil is in the solid phase, while convection is the dominant heat transfer mode when co_oil melts and becomes liquid [35]. The amount of heat absorbed by co_oil can be determined by the following energy balance equation [50]:

$$
m c \frac{d T}{d t}=\alpha A_{c}\left(T_{a}-T\right)
$$

where $m$ is the mass of co_oil, $c$ is the specific heat of co_oil, $\alpha$ is the heat transfer coefficient of co_oil, and $A_{c}$ is the convective heat-transfer area of the container. Equation (1) can be integrated from initial 
to final time in a certain phase of co_oil (sensible solid, solid to liquid phase change and sensible liquid) to give a set of equations (see Figure 1a):

$$
\begin{gathered}
A_{\mathrm{I}}=\int_{t_{0}}^{t_{1}}\left(T_{a}-T\right) d t ; m c_{s}\left(T_{1}-T_{0}\right)=\alpha A_{c} A_{\mathrm{I}} \\
A_{\mathrm{II}}=\int_{t_{1}}^{t_{2}}\left(T_{a}-T\right) d t ; m h_{m}=\alpha A_{c} A_{\mathrm{II}} \\
A_{\mathrm{III}}=\int_{t_{2}}^{t_{3}}\left(T_{a}-T\right) d t ; m c_{l}\left(T_{r}-T_{1}\right)=\alpha A_{c} A_{\mathrm{III}}
\end{gathered}
$$

where $c_{S}$ and $c_{l}$ are the solid and liquid specific heats of co_oil, and $h_{m}$ is the melting heat of co_oil related to latent heat at the solid-liquid phase transition. The set values of $\left(A_{\mathrm{I}}, A_{\mathrm{II}}, A_{\mathrm{III}}\right)$ correspond to the area of sensible solid $\left(t_{0}-t_{1}\right)$, latent phase $\left(t_{1}-t_{2}\right)$, and sensible liquid $\left(t_{2}-t_{3}\right)$. From these equations, one can see that the amount of heat exchanged is proportional to the area under the temperature curve against environmental temperature for each indicated phase.

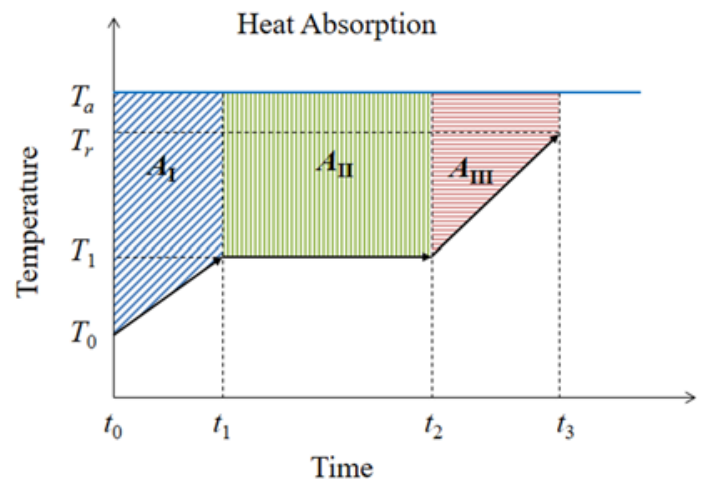

(a)

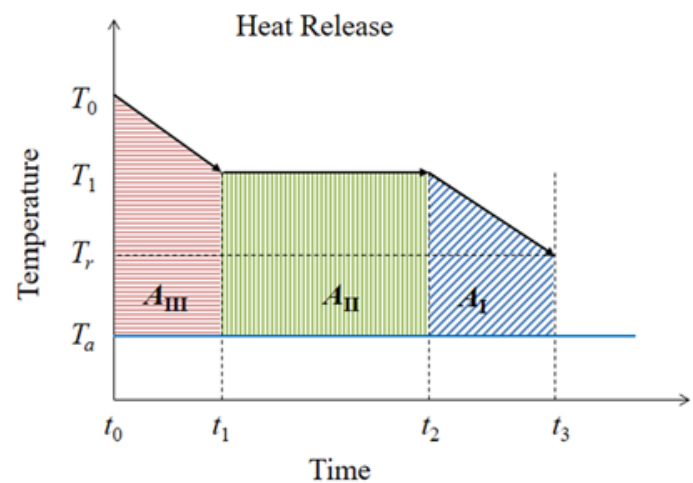

(b)

Figure 1. Illustration for: (a) The heat absorption and (b) the heat release of co_oil.

The similar energy balance and a set of equations for heat released are given by, (see Figure 1b):

$$
\begin{gathered}
m c \frac{d T}{d t}=-\alpha A_{c}\left(T-T_{a}\right) \\
A_{\mathrm{III}}=\int_{t_{2}}^{t_{3}}\left(T-T_{a}\right) d t ; m c_{s}\left(T_{1}-T_{r}\right)=\alpha A_{c} A_{\mathrm{III}} \\
A_{\mathrm{II}}=\int_{t_{1}}^{t_{2}}\left(T-T_{a}\right) d t ; m h_{m}=\alpha A_{c} A_{\mathrm{II}} \\
A_{\mathrm{I}}=\int_{t_{0}}^{t_{1}}\left(T-T_{a}\right) d t ; m c_{l}\left(T_{0}-T_{1}\right)=\alpha A_{c} A_{\mathrm{I}}
\end{gathered}
$$

This study aims to identify the basic design requirements of co_oil cells as room air temperature control agents, including the factors of cell size and co_oil mass. We conducted three experiments, as follows: (1) Qualitative evaluations of the total thermal energy storage potential of co_oil; (2) 
evaluation of the performance of different co_oil cell sizes under a typical room air temperature, where the latent phase had not fully been established; and (3) estimating the required mass of co_oil in an air cooling system. Figure 2 show the schematic diagram and photographs of experimental work.

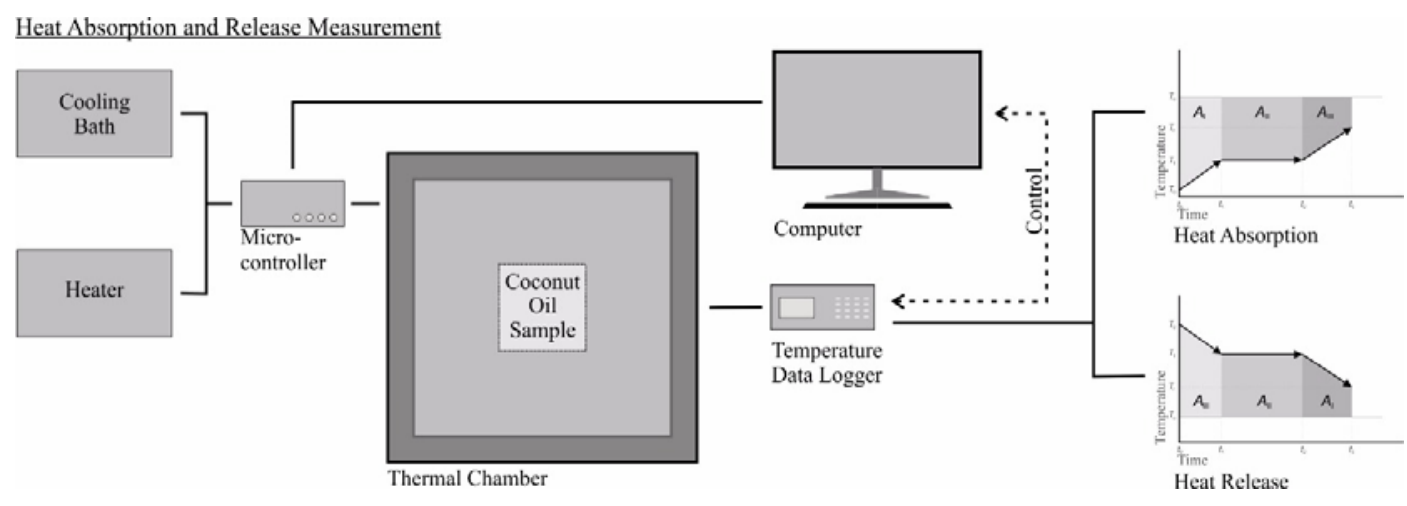

(a)

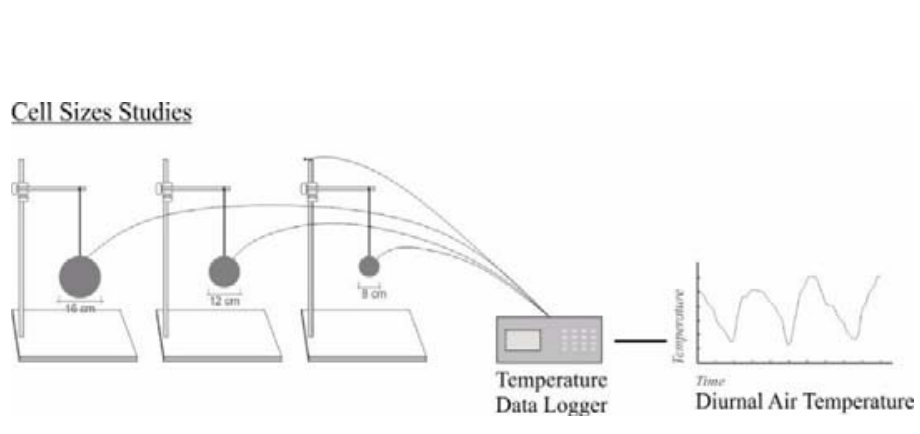

(b)

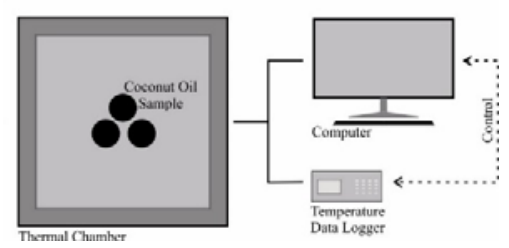

(d)

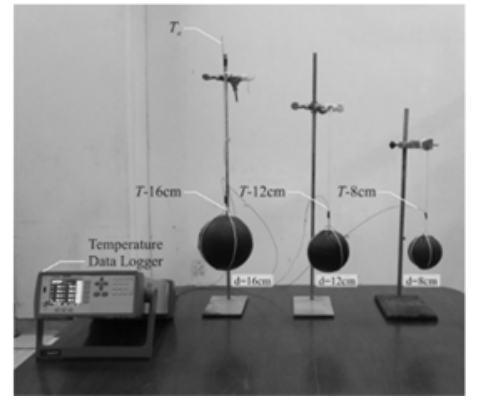

(c)

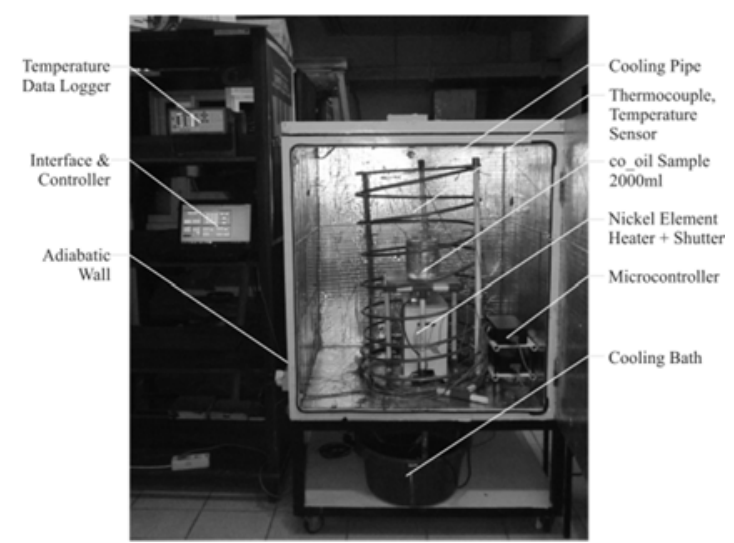

(e)

Figure 2. (a) The schematic diagram for heat absorption and release measurement. (b) The schematic diagram for the cell sizes studies, and (c) the photograph of coconut oil cell. (d) The schematic diagram for the measurement in the thermal chamber, and (e) the photograph of the thermal chamber.

The measurements were carried out in a typical room air environment and a thermal chamber was used to replicate the desired air environment. The cubic thermal chamber had an internal volume of $0.64 \mathrm{~m}^{3}$ and highly insulated walls, which were made from two cement layers that were $6 \mathrm{~mm}$ thick each, and had a $20 \mathrm{~mm}$ Styrofoam layer inserted between them. The inner surface of this chamber was covered with an aluminum foil. The chamber was thus intended to function as an adiabatic 
container. The chamber was equipped with a nickel electrical heating element $(350 \mathrm{~W})$ at the center of the chamber for warming, which was surrounded by a vertical copper piping system that allowed water to cool the chamber.

The first part of the experiment was conducted to examine the thermal properties of co_oil, including natural heat absorption and release at certain time intervals between certain temperatures to ascertain the effectiveness of exchanging thermal energy. A large amount of co_oil was placed into a $2 \mathrm{~L}$ glass container. The experiments were performed using a thermal chamber, with the cooling temperature set to $7{ }^{\circ} \mathrm{C}$, while heating was induced naturally by turning off the cooling engine. The temperature was measured every $15 \mathrm{~min}$ for $48 \mathrm{~h}$ by placing the temperature sensor at the perimeter $\left(T_{1}\right)$ and core $\left(T_{2}\right)$ areas of the sample, to provide a temporal overview of temperature changes and identify the co_oil's melting point.

This was followed by second co_oil performance measurements, which were contained in plastic cells that were $8 \mathrm{~cm}, 12 \mathrm{~cm}$, and $16 \mathrm{~cm}$ in size, each of them corresponded to $0.2,0.75$, and $1.75 \mathrm{~kg}$. Each cell was equipped with a sensor at the core. These experiments were conducted to study the characteristics of co_oil in different cell sizes through variations of its temperature in response to the natural air environment.

In the final part of the experiment, variation in co_oil mass was measured to analyze the performance of co_oil as a temperature control agent in the thermal chamber. For this experiment, the chamber was set to a temperature of $39^{\circ} \mathrm{C}$, which represents the maximum temperature of the tropical area in the afternoon. Starting from an initial temperature of $10^{\circ} \mathrm{C}$ and solid physical state, the heat absorption study of the co_oil was investigated by measuring air temperature changes by variation in co_oil mass, where the final physical state of co_oil was liquid with a varied final temperature between $35-37^{\circ} \mathrm{C}$. The air temperature decrement was determined after $1.5 \mathrm{~h}$ measurement, and the temperature was stable for about $2 \mathrm{~h}$ for each mass variations. The results of this study will be used to determine the minimum amount of co_oil needed to achieve effective temperature regulation for a typical Indonesian or tropical living room.

\section{Results}

\subsection{Thermal Characteristics and Heat Exchange Performance of Co_Oil as a TES Medium}

The results for the time-dependent temperature for the melting process of co_oil are shown in Figure 3a. The temperature data differed between $T_{1}$ and $T_{2}$; the perimeter area of the sample had a closer temperature to the environment compared to the core area. This demonstrates that heat transport inside the co_oil requires a long time due to its bad thermal conductivity.

During the solid phase, the co_oil heat absorption was characterized by a temperature increase, signifying the sensible solid heat region, with $T_{2}$ values lower than those of $T_{1}$. At temperatures of around $20^{\circ} \mathrm{C}$, the co_oil began to melt, and smaller $T_{1}$ and $T_{2}$ temperature gradients were observed, signifying latent phase transition (solid-liquid). The co_oil was primarily composed of numerous saturated and unsaturated fatty acids, ranging from short and medium to long chains, and they each had different melting temperatures [51]. The melting transition of co_oil was not rapid, and occured continuously with small temperature increases. Finally, the sensible liquid heat region (Liquid) was characterized by a steep increase in temperature towards the air temperature.

The observations of the solidification process (Figure $3 \mathrm{~b}$ ) indicate that the solidification process of co_oil occurs at temperatures below its melting range, with the monotonous decrease of air temperature due to the work of the cooling engine. The same $T_{1}$ and $T_{2}$ profiles were observed in this process. During the cooling process, the sensible heat release of co_oil began at temperatures around $30{ }^{\circ} \mathrm{C}$, until the temperature reached about $17^{\circ} \mathrm{C}$. The co_oil sample released the latent heat and it began to solidify at a relatively constant temperature of $17^{\circ} \mathrm{C}$. No supercooling was observed, as indicated by a dip in the curve, which might be due to a relatively large amount of sample used in the experiment [52]. From comparing the temperature values of $T_{1}$ at the perimeter and $T_{2}$ at the core of the sample, 
the results show that the perimeter region of the sample solidified earlier than the core. The heat released by the solid region was indicated by the increase of the slope, compared with that of the latent region.

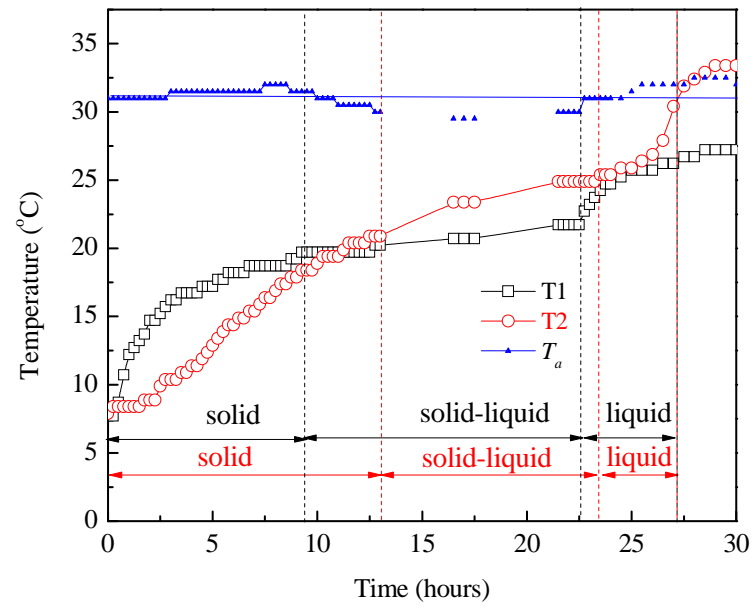

(a)

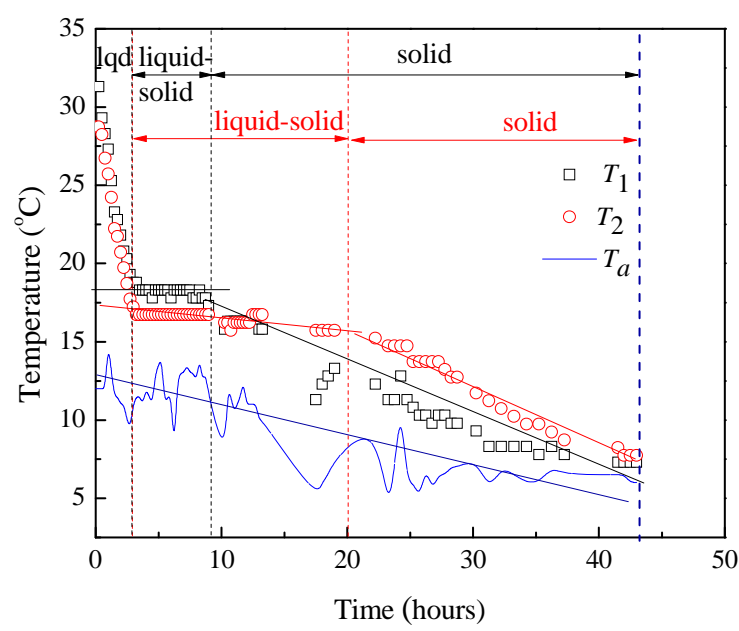

(b)

Figure 3. The time-dependent temperature curves for (a) melting and (b) solidification of co_oil samples. The regions of sensible solid heat, latency, and sensible liquid heat are each denoted by solid, solid-liquid, and liquid. The periods of those phases were different for the two thermometers as indicated by the vertical dashed line. The solid lines indicate the linear extrapolation as a guide for the eye.

From the co_oil melting and solidification curves (Figure 3a,b), the estimated proportionality amount of heat exchanged between co_oil and the environment as the area below the co_oil temperature curve towards the air environment $\left(T_{a}\right)$ can be calculated, based on Equations (2) and (4). Figure 4 shows column charts of the composition of heat absorption by co_oil (Figure 4a) and heat released from co_oil (Figure $4 \mathrm{~b}$ ) in three distinct regions. It is to be noted that heat absorption or heat release composition is the identification of sensible solid phase, solid-liquid phase change, and sensible liquid phase during heat absorption or heat release processes.

These figures show that the amount of heat exchanged differs between the three indicated regions. The amount of absorbed heat decreased in the following order, each of them with different temperature ranges: sensible solid $\left(8-21^{\circ} \mathrm{C}\right)$, solid-liquid phase change $\left(20-25{ }^{\circ} \mathrm{C}\right)$, and sensible liquid $\left(22-31^{\circ} \mathrm{C}\right)$, and the amount of heat released increased in the opposite order: sensible liquid $\left(31-16.5^{\circ} \mathrm{C}\right)$, liquid-solid phase change $\left(18-16^{\circ} \mathrm{C}\right)$, and sensible solid $\left(18-7.5^{\circ} \mathrm{C}\right)$. The sum of latent heat and sensible liquid were approximately the same for heat absorption and heat release processes, thus indicating that the solid-liquid phase transition of co_oil did not occur at a certain temperature, instead, it occured simultaneously with a temperature change. The capability of co_oil to absorb heat at temperatures exceeding $20^{\circ} \mathrm{C}$ is approximately $50 \%$ of its total value. This indicates that co_oil can sufficiently decrease indoor air temperature in tropical countries. This is consistent with the ability of co_oil to store a large amount of heat between 22 and $33^{\circ} \mathrm{C}$, as indicated by the differential scanning calorimetry (DSC) [33]. This temperature range is close to the comfortable living temperature range for people in a tropical climate, although the extent of co_oil's ability to absorb and release heat varies at different temperatures [33]. In contrast, co_oil can release heat below $17^{\circ} \mathrm{C}$. This temperature is below the lowest that can be obtained indoors, indicating that heat should be released outdoors during the night when the air temperature is lower. The outdoor night cooling method is only intended for the peak shifting and decreasing of the daytime temperatures. As an alternative method of getting 
out the TES during the night, some experts use the fan to increase the heat exchange between co_oil and air [12-16,31].
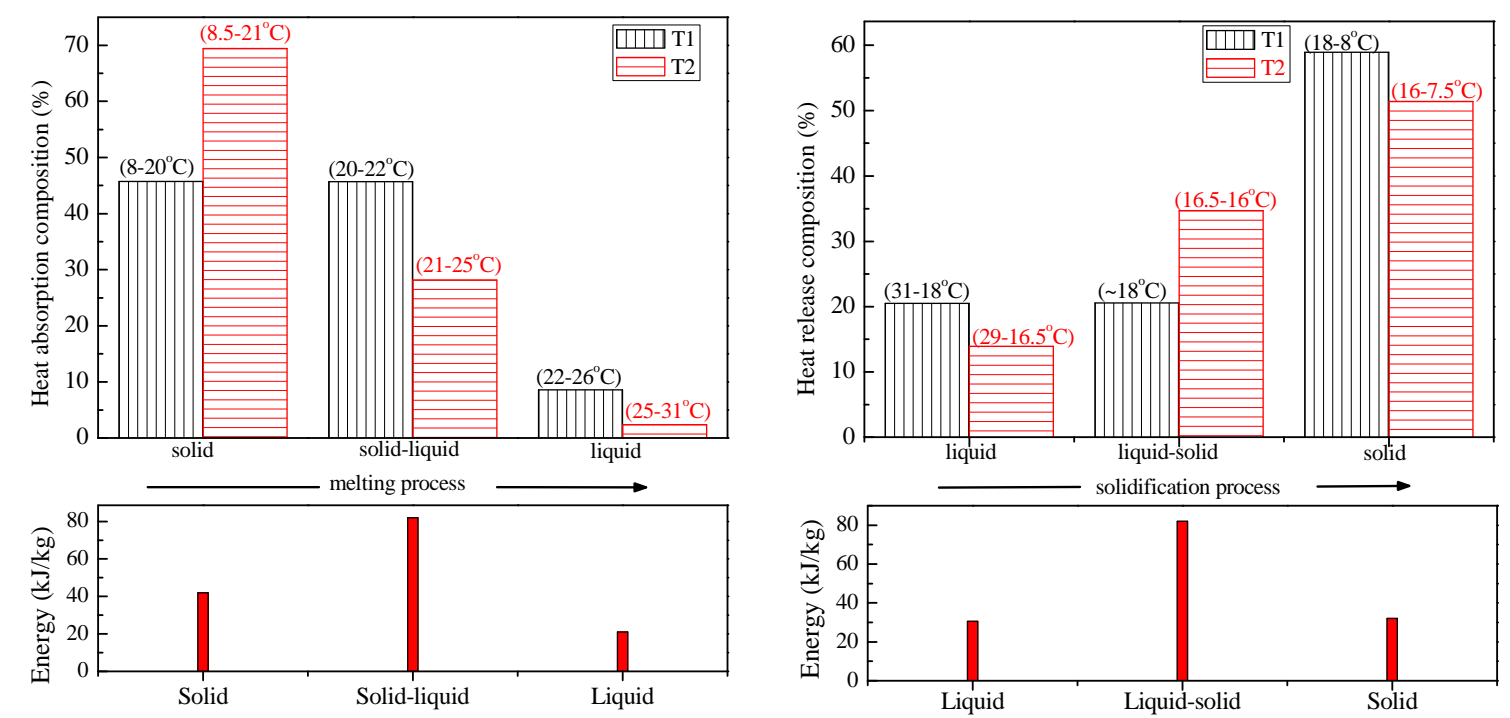

(a)

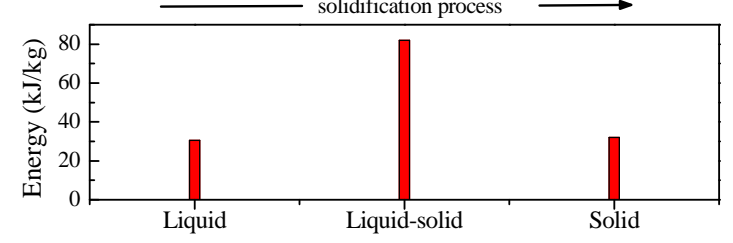

(b)

Figure 4. The estimated amount of heat exchanged from the co_oil during (a) heat absorption and (b) heat release processes. The temperature ranges for each phase region are also indicated for the two thermometers.

In addition, based on the values of solid and liquid specific heats and the heat of fusion from Reference [32], we have done an estimation for the values of heat absorption and heat release per unit mass of coconut oil, and the results are shown at the bottom of Figure 4. From this figure, it is seen that latent heat related to the solid to liquid phase transition or vice versa, is the largest among sensible heat in the solid and liquid phases.

\subsection{Cell-Size Characteristics of Co_Oil as a TES with Regard to Room Air Temperature}

The characterization for co_oil cell sizes was obtained in two series of experiments, which covered day heating and night cooling by comparing the co_oil's temperature in three 8-cm, 12-cm, and 16-cm-sized cells. This study aimed to identify the most appropriate co_oil cell size for reducing the extreme values of day and night air temperatures of an isolated room by absorbing and releasing heat during co_oil charging and discharging periods. Other effects were related to the length of the delay period between charging and discharging, due to the expectation of a comfortable air temperature range for people.

The effects of day heating and night cooling on co_oil in different cell sizes can be seen in the graphic of charging and discharging, when co_oil temperature differs from the air temperature of the environment. The charging process occurs when co_oil absorbs heat from the surrounding environment during the day, while the discharging process occurs when co_oil releases the absorbed heat at night. Figure 5 shows an illustration of the fluctuations in co_oil temperatures in different cell sizes, compared with the ambient temperature. The co_oil can reduce air temperature variation, where the co_oil in smaller cell sizes shows temperatures close to the ambient temperature and leads to higher temperature variations. 
(a)
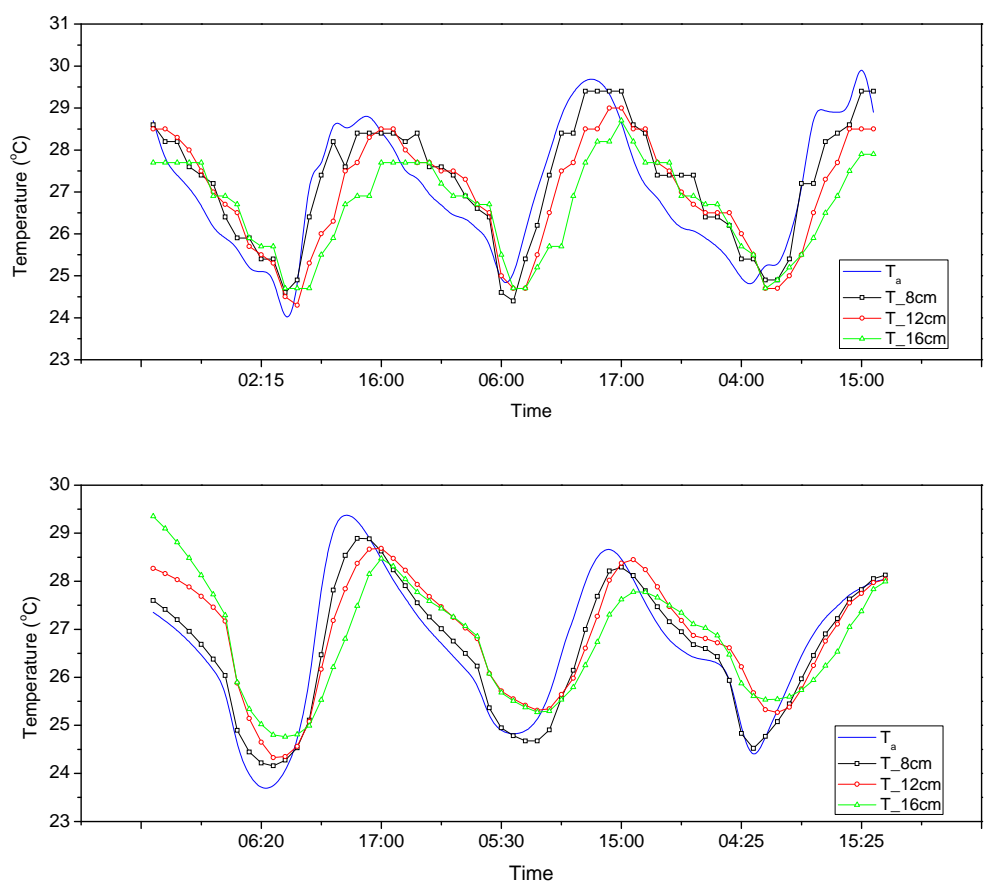

Figure 5. Illustration of the normal air temperature profile and dynamics of co_oil's temperatures, measured from three different cells of $8 \mathrm{~cm}, 12 \mathrm{~cm}$, and $16 \mathrm{~cm}$ for (a) first set, and (b) second set of experiments; each set of data were performed for three days.

\subsubsection{Temperature Difference and Time-Delay Analysis}

In a tropical environment, air temperature increases in the morning until noon and gradually decreases in the afternoon until the night to early morning. The mass of co_oil that has been in a thermal equilibrium at a certain time will enter non-thermal equilibrium at other times. The co_oil can continue to work during the day and night because of the dynamics of air temperature changes and can reduce the variation between day and night air temperatures. A potential use of co_oil for controlling air temperature is indicated by the maximum temperature difference between air temperature and co_oil in each cell size that contained different amounts of sample, with the average values shown in Figure 6a.

From Figure 6a, it can be seen that the temperature differences are proportional to co_oil cell size, where bigger cell sizes have higher temperature differences. Since the co_oil process is based on heat exchange due to temperature differences with the air temperature, smaller temperature difference values signify more energy balance between the air and co_oil. In contrast, higher temperature difference values signify its capability in TES, although its effectiveness should be kept in mind since large amounts of Co_oil with larger cell size do not guarantee that all samples contribute as a TES medium, due to its low thermal conductivity.

A benefit of temperature differences is the time delay for the maximum co_oil temperature, compared to those for the peak of ambient temperature, which is shown in Figure $6 \mathrm{~b}$. The implementation of time delay in the co_oil cells is important for managing its working range to decrease air temperature further. From this figure, it can be seen that the larger cells had a longer time delay. Longer time delays give longer shifting of peak time, and further decreases air temperature. This means that bigger co_oil cells work for longer than the small ones during the daytime. 


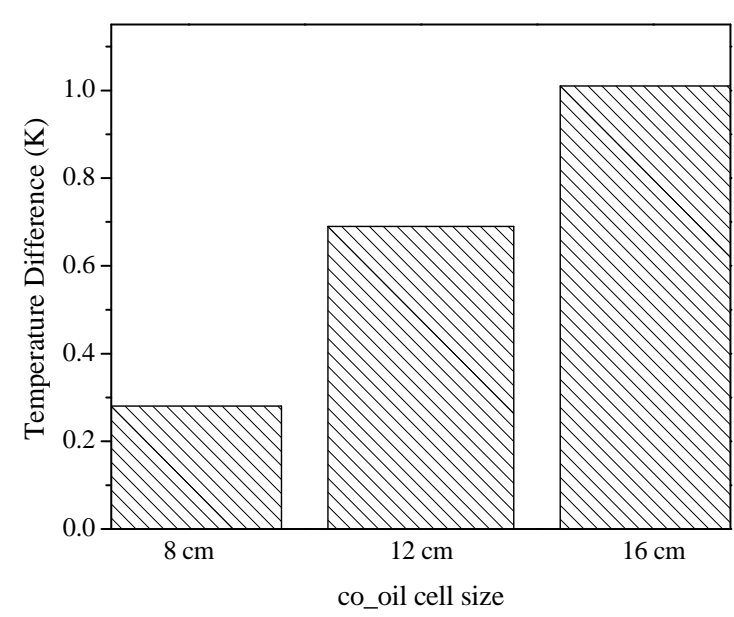

(a)

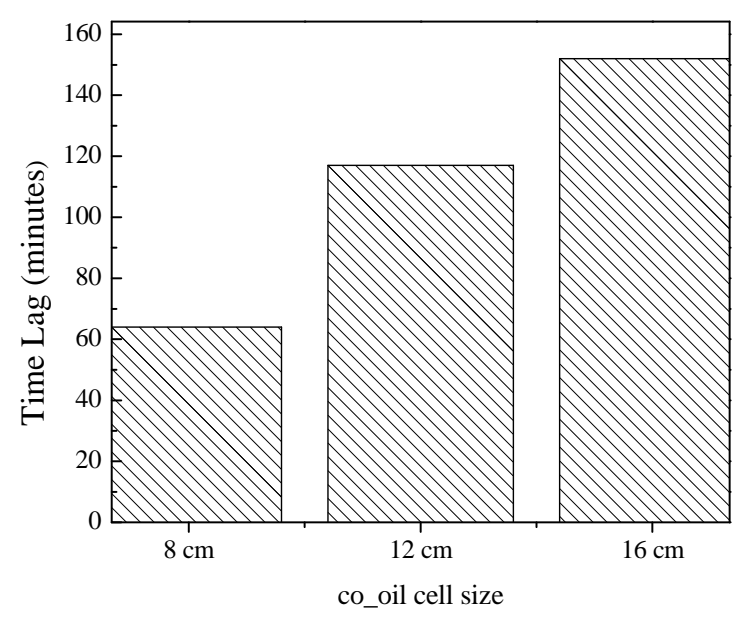

(b)

Figure 6. (a) The differences in maximum temperature between co_oil cells and air temperature and (b) its associated change in time lag, signifying the average time delay.

\subsubsection{Charging-Discharging Effectiveness Analysis}

The amount of heat exchanged by convection, related to the charging and discharging processes of co_oil, was estimated from the area between co_oil temperature and air temperature. As shown in Figure 7, charging capacity was increased by an increase of co_oil cell size, due to it being directly related to the amount of co_oil contained in the cell. Charging capacity was higher than the discharging capacity, which indicates that heat absorption of co_oil can occur easier than heat release. The difference is most noticeable in the $16 \mathrm{~cm}$ cell, while it could be ignored for the $12 \mathrm{~cm}$ cell. To identify the impact of this, we further analyzed the average temperature of co_oil in each cell.

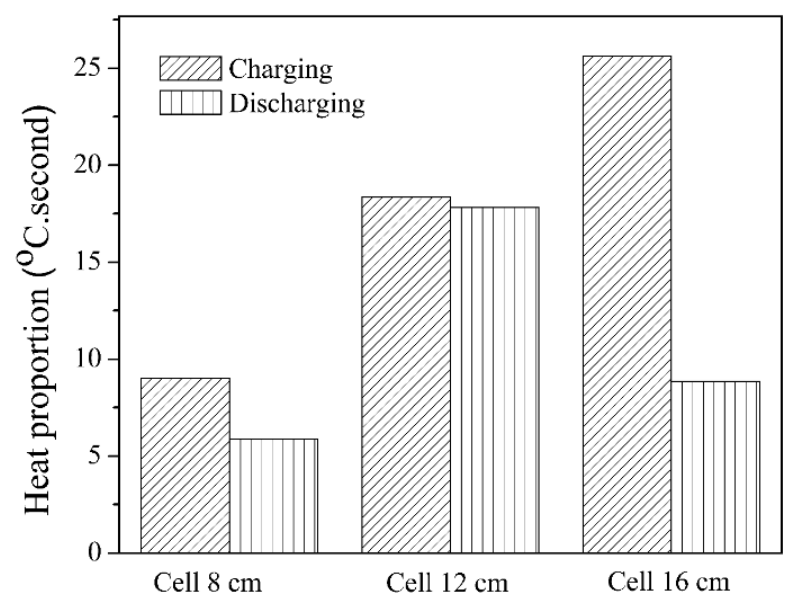

Figure 7. The estimated heat exchanges of co_oil cells, consisting of charging and discharging capability for three different cell sizes.

The average co_oil temperatures in each cell for the three measurement days and the first set of experiments are shown in Figure 8. Coconut oil with a cell size of $8 \mathrm{~cm}$ shows the average temperature value that follows the average daily air temperature increase so that the value is highest compared to other cell sizes, and even higher than the average air temperature value. This might be due to the fact that co_oil in $8 \mathrm{~cm}$ cells experience imbalances between charging-discharging capacities that make the temperature increase gradually. On the other hand, the lowest average temperature for co_oil in $16 \mathrm{~cm}$ 
cells might be due to only a part of the sample contributing to the heat storage performance, due to the large amounts of co_oil contained.

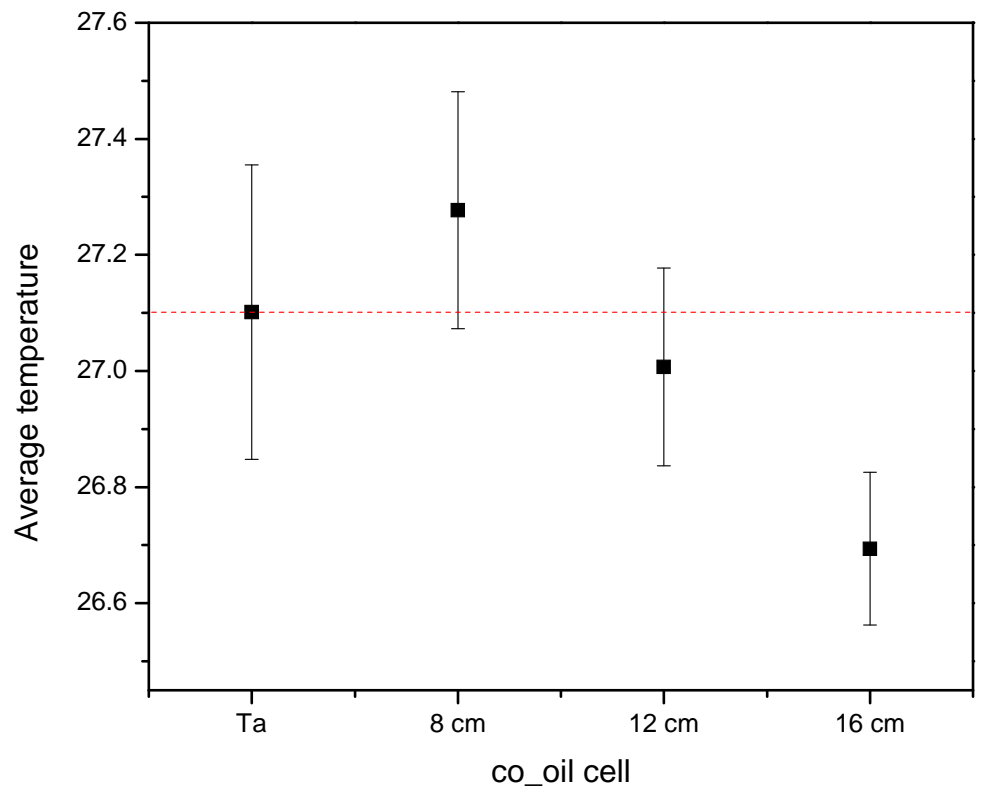

Figure 8. The average temperature for three cycles for the different co_oil cell sizes. This figure also shows average air temperature for comparison.

To study the behavior of the charging and discharging processes in more detail, we analyzed the increasing and decreasing temperature periods for all co_oil cells. From the results in Figure 9, it can be identified that all of the co_oil cells show similar charging and discharging periods, irrespective of cell size. Charging and discharging periods may not be directly related to co_oil cell size, which only controls the amount of co_oil mass that is involved in absorbing and releasing heat.

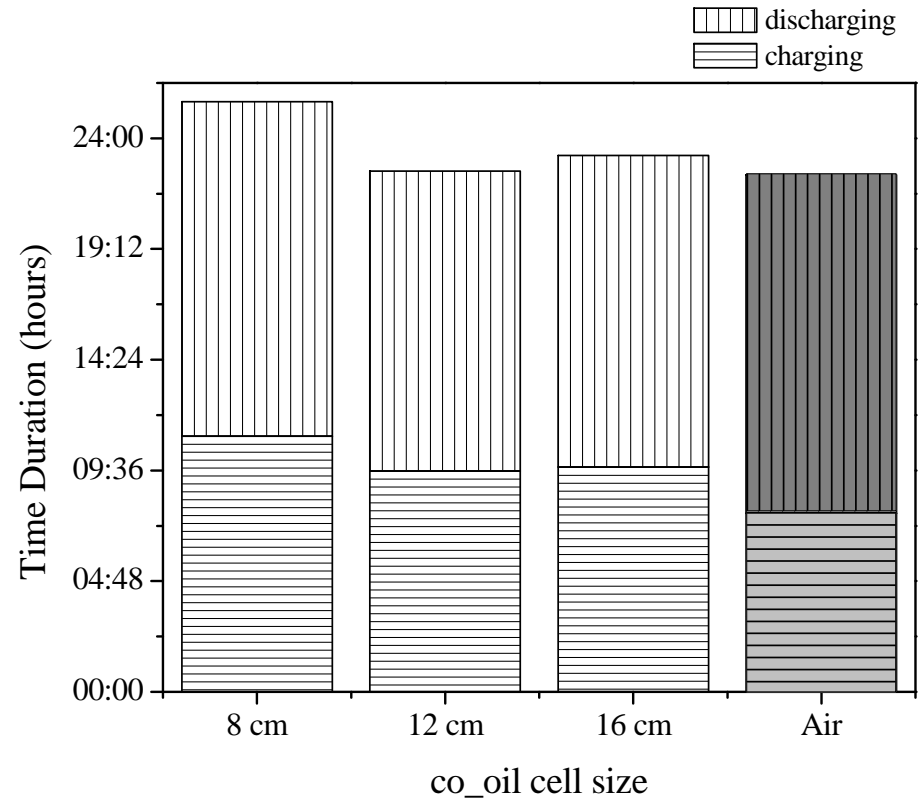

Figure 9. The column chart for average charging-discharging periods of co_oil cells of 8, 12, and $16 \mathrm{~cm}$, compared to heating and cooling periods of air temperature. 
On average, it can be seen that the charging period was shorter than the discharging period, i.e., it occurs for about $10 \mathrm{~h}$ from morning to afternoon, while the discharging process occurs for about 13:40 hour's duration, from afternoon to the early morning of the next day. Heating in the charging process is intense, while the discharging process involves gradual heat release.

\subsection{Coconut Oil Cells as a Temperature Control Agent}

The capability of co_oil in decreasing air temperature was further measured in a thermal chamber. The capability of co_oil mass to decrease the air temperature is shown in Figure 10. From the figure, additional co_oil mass will result in higher reductions of air temperature linearly, which means that the amount of co_oil is significant in decreasing ambient temperature.

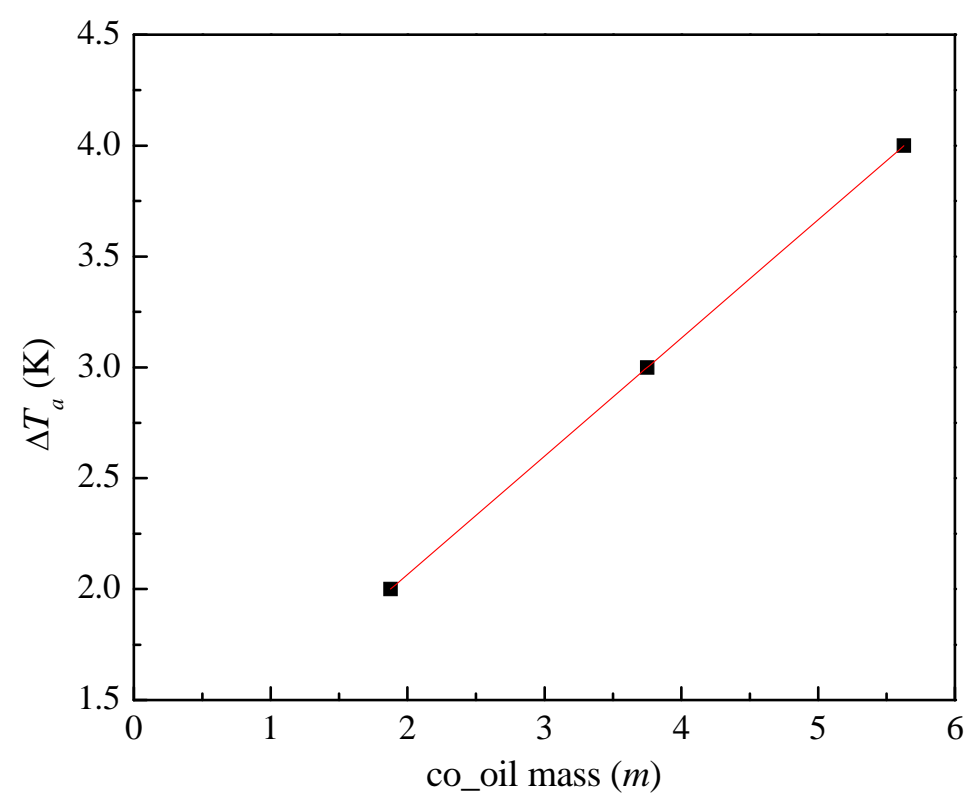

Figure 10. Air temperature decrease as a function of co_oil mass and the linear fit by Equation (5).

The thermal mass capability of co_oil for air temperature control $(x)$ can be calculated by the following formula:

$$
\Delta T_{a}=\frac{x}{V_{r}} m
$$

where $m$ is the mass of co_oil, $V_{r}$ is the room volume where the co_oil cells are placed, and $\Delta T_{a}$ is the air temperature decrement value. The resulted value of $x$ as the slope of the graph times $V_{r}$ is equal to $0.533 \mathrm{~K} . \mathrm{m}^{3} / \mathrm{kg}$. The intercept of the graph is not zero due to existing thermal mass effect of the thermal chamber. As temperature control agents, the most important aspect of co_oil cells is their ability to control the maximum daytime air temperature. With the simple formula stated in Formula (5), the amount of co_oil for one typical $3 \times 4 \mathrm{~m}^{2}$ room of an Indonesian house can be estimated. As an example to decrease air temperature by $2.0-2.5 \mathrm{~K}$, the amount of co_oil required is about $135-170 \mathrm{~kg}$. We note that that relatively large amounts of co_oil mass could be utilized as a panel of the partition wall, ceiling devices, furniture, etc. in the room, where the co_oil is contained in the form of cells, as illustrated in Figure 11a. In addition, Figure 11b shows the heat exchange between co_oil and its air environment. The heat exchanger as shown in Figure 11 implements the indirect concept [12], so that the airflow inside the heat exchange unit does not interfere with the occupants. This semi-active technology model can facilitate the heat exchange with outer space by adding ducts that connecting outer space and heat exchanger units. Alternatively, one can use a separate space such as a plenum or raised floor with additional ducts, so that the cooler air from outdoor is blown in while the warm air is 
blown out. This technology model can facilitate outdoor night cooling during the rainy season with the warm air temperature at night, so that the discharging process requires a lower outdoor temperature.

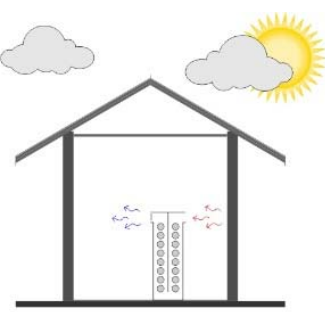

Indoor Charging

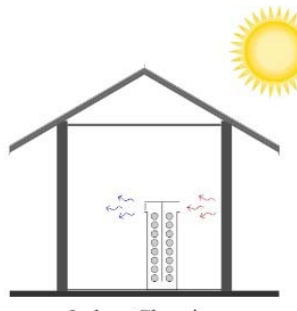

Indoor Charging

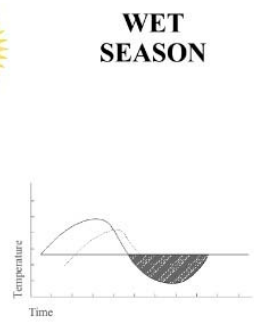

DRY

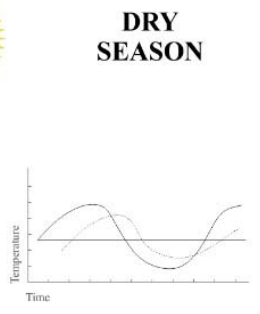

(a)

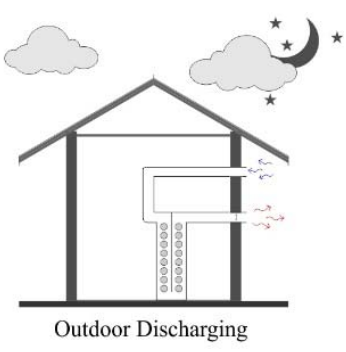

Warm Air
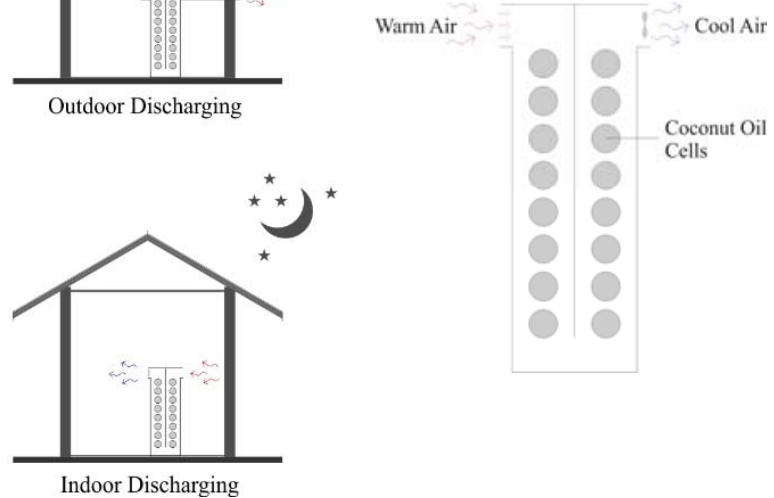

Indoor Discharging

Figure 11. (a) Conceptual design of co_oil as TES in a house and (b) illustration of heat exchange between co_oil and its air environment.

In the humid night air, the potential for dew point evaporative cooling on the co_oil cell is large enough so that the discharging process can play more intensively. In addition, the use of water spray on heat exchanger units will be highly effective in a dry air environment [53]. A similar technology to accommodate the outdoor night cooling requirement is pivot wall technology in which each side of the wall alternates on the outer side of the room [54].

Architects and interior designers should pay attention to this possibility for the energy conservation program, in order to reduce the electrical energy consumption for AC [11]. The use of coconut oil as a passive air conditioner is appropriate and affordable because of its relatively low price and easily constructed with low construction cost.

\section{Conclusions}

In this paper, we demonstrated the performance of coconut oil (co_oil) for a potential TES system in tropical countries, such as Indonesia. Coconut oil could perform as a temperature control for indoor air temperatures above $20^{\circ} \mathrm{C}$, although only about $50 \%$ of its capability for absorbing or releasing heat was involved. The latent heat charging process occurs at a temperature range of $20-25^{\circ} \mathrm{C}$, while the latent heat discharging processes occur at relatively low temperatures of $16-18^{\circ} \mathrm{C}$. It should, therefore, be possible to arrange an outdoor night cooling system for effective discharging.

Due to its low thermal conductivity, related to heat transfer, the volume of the co_oil cell, which influences its performance as a thermal control agent, should be considered. From the experiment that used $8 \mathrm{~cm}, 12 \mathrm{~cm}$, and $16 \mathrm{~cm}$ co_oil cells, we found that the temperature of all of the co_oil cells followed the dynamics of the ambient temperature, with smaller co_oil cell sizes having smaller differences with air temperature and smaller time delays. The average temperature of the $8 \mathrm{~cm}$ co_oil cells tended to increase with time, which was due to the fact that the charging capacity was larger than its discharging capacity. The average temperature of the $16 \mathrm{~cm}$ co_oil cells, however, was relatively low and constant, which suggests that only part of the sample contributed to energy storage. The co_oil with a cell size of $12 \mathrm{~cm}$ showed a balance between charging and discharging capacities, which could be the most ideal co_oil cell size for the direct heat exchange with the environment. 
The capability of co_oil for decreasing indoor air temperature per unit of air volume was measured by experiments conducted in a thermal chamber. It was found that the estimated co_oil mass required to decrease the maximum air temperature of a typical $3 \times 4 \mathrm{~m}^{2}$ room size by $2.0-2.5 \mathrm{~K}$ in the afternoon is about $135-170 \mathrm{~kg}$. We note that the potential of co_oil as a TES for a temperature control system in Indonesia could be explained by the above prediction, as the amount of co_oil required is achievable.

Author Contributions: S.W. and I.M.S. designed the study; S.W. and D.K. conceived the study; Z.F. and W.A.P. collected the data; S.W., Z.F., and W.A.P. analyzed the data; S.W. and I.M.S. wrote the manuscript; D.K. helped with editing the manuscript.

Funding: This research was funded by Research Schema of Desentralisasi ITB No. 680.g/I1.C10/KU/2014, DIKTI Indonesia.

Conflicts of Interest: The authors declare no conflict of interest.

\section{References}

1. Japan International Cooperation Agency (JICA). Development of Evaluation Method on Energy Efficiency and Conservation Policy (MACC); Final Report; JICA: Tokyo, Japan, 2015.

2. Braun, J.E. Load control using building thermal mass. Trans. ASME 2003, 125, 292-301. [CrossRef]

3. Dinçer, I.; Rosen, M.A. Thermal Energy Storage (TES) Methods. In Thermal Energy Storage. Systems and Applications, 2nd ed.; John Wiley \& Sons, Ltd.: Chichester, UK, 2011; pp. 83-187, ISBN 978-0-470-97073-7.

4. Balaras, C.A. The role of thermal mass on the cooling load of buildings. An overview of computational methods. Energy Build. 1996, 24, 1-10. [CrossRef]

5. Wilson, B.Y.A. Thermal Storage Wall Design Manual, 1st ed.; New Mexico Solar Energy Association: Albuquerque, NM, USA, 1979.

6. Karlsson, J. Possibilities of Using Thermal Mass in Buildings To save Energy, Cut Power Consumption Peaks and Increase the Thermal Comfort. Master's Thesis, Lund University, Lund, Sweden, 2012.

7. Burdick, A. Strategy Guideline: Accurate Heating and Cooling Load Calculations; U.S. Department of Energy: Pittsburgh, PA, USA, 2011.

8. Zhang, Y.; Zhou, G.; Lin, K.; Zhang, Q.; Di, H. Application of latent heat thermal energy storage in buildings: State-of-the-art and outlook. Build. Environ. 2007, 42, 2197-2209. [CrossRef]

9. Wonorahardjo, S. New concepts in districts planning, based on heat island investigation. Procedia Soc. Behav. Sci. 2012, 36, 235-242. [CrossRef]

10. Damiati, S.A.; Zaki, S.A.; Rijal, H.B.; Wonorahardjo, S. Field study on adaptive thermal comfort in office buildings in Malaysia, Indonesia, Singapore, and Japan during hot and humid season. Build. Environ. 2016, 109, 208-223. [CrossRef]

11. De Gracia, A.; Cabeza, L.F. Phase change materials and thermal energy storage for buildings. Energy Build. 2015, 103, 414-419. [CrossRef]

12. Haase, M.; Andresen, I. Thermal Mass Concept, State of the Art; SINTEF Building and Infrastructure: Trondheim, Norway, 2007.

13. Brambilla, A.; Bonvin, J.; Flourentzou, F.; Jusselme, T. On the Influence of Thermal Mass and Natural Ventilation on Overheating Risk in Offices. Buildings 2018, 8, 47. [CrossRef]

14. Tyagi, V.V.; Buddhi, D. PCM thermal storage in buildings: A state of art. Renew. Sustain. Energy Rev. 2007, 11, 1146-1166. [CrossRef]

15. Tyagi, V.V.; Buddhi, D.; Kothari, R.; Tyagi, S.K. Phase change material (PCM) based thermal management system for cool energy storage application in building: An experimental study. Energy Build. 2012, 51, 248-254. [CrossRef]

16. Tyagi, V.V.; Pandey, A.K.; Buddhi, D.; Kothari, R. Thermal performance assessment of encapsulated PCM based thermal management system to reduce peak energy demand in buildings. Energy Build. 2016, 117, 44-52. [CrossRef]

17. Kuznik, F.; David, D.; Johannes, K.; Roux, J.-J. A review on phase change materials integrated in building walls. Renew. Sustain. Energy Rev. 2011, 15, 379-391. [CrossRef]

18. Oliver, A.; Garc, A.; Neila, F.J. Physical and mechanical characterization of gypsum boards containing phase change materials for latent heat storage. Mater. Constr. 2011, 61, 465-484. 
19. Pons, O.; Aguado, A.; Fernández, A.I.; Cabeza, L.F.; Chimenos, J.M. Review of the use of phase change materials (PCMs) in buildings with reinforced concrete structures. Mater. Constr. 2014, 64, 1-11. [CrossRef]

20. Mettawee, E.B.S.; Eid, E.I.; Amin, S.A.M. Experimental study of PCM thermal storage. J. Appl. Sci. Res. 2012, 8, 3424-3432.

21. Akeiber, H.J.; Hosseini, S.E.; Wahid, M.A.; Hussen, H.M.; Mohammad, A.T. Phase Change Materials-Assisted Heat Flux Reduction: Experiment and Numerical Analysis. Energies 2016, 9, 30. [CrossRef]

22. Sarbu, I.; Sebarchievici, C. A Comprehensive Review of Thermal Energy Storage. Sustainability 2018, $10,191$. [CrossRef]

23. Kiran, T.R.; Rajput, S.P.S. Cooling Capacity and Energy Saving Potential of Dew Point Evaporative Cooling System for Indian Buildings. Int. J. Renew. Energy Res. 2013, 3, 73-78.

24. Sutjahja, I.M.; Silalahi, A.O.; Sukmawati, N.; Kurnia, D.; Wonorahardjo, S. Variation of thermophysical parameters of $\mathrm{PCM} \mathrm{CaCl}_{2} \cdot 6 \mathrm{H}_{2} \mathrm{O}$ with dopant from T-history data analysis. Mater. Res. Express 2018, 5, 034007. [CrossRef]

25. Fleischer, A.S. Thermal Energy Storage Using Phase Change Materials: Fundamentals and Applications; Springer: Villanova, PA, USA, 2015.

26. Isa, M.H.M.; Zhao, X.; Yoshino, H. Preliminary Study of Passive Cooling Strategy Using a Combination of PCM and Copper Foam to Increase Thermal Heat Storage in Building Façade. Sustainability 2010, 2, 2365-2381. [CrossRef]

27. Oya, T.; Nomura, T.; Tsubota, M.; Okinaka, N.; Akiyama, T. Thermal conductivity enhancement of erythritol as PCM by using graphite and nickel particles. Appl. Therm. Eng. 2013, 61, 825-828. [CrossRef]

28. Wi, S.; Seo, J.; Jeong, S.G.; Chang, S.J.; Kang, Y.; Kim, S. Thermal properties of shape-stabilized phase change materials using fatty acid ester and exfoliated graphite nanoplatelets for saving energy in buildings. Sol. Energy Mater. Sol. Cells 2015, 143, 168-173. [CrossRef]

29. Teng, T.; Yu, C. Characteristics of phase-change materials containing oxide nano-additives for thermal storage. Nanoscale Res. Lett. 2012, 7, 1-10. [CrossRef] [PubMed]

30. Regin, A.F.; Solanki, S.C.; Saini, J.S. Heat transfer characteristics of thermal energy storage system using PCM capsules: A review. Renew. Sustain. Energy Rev. 2008, 12, 2438-2458. [CrossRef]

31. Temirel, M.; Hu, H.; Shabgard, H.; Boettcher, P.; McCarthy, M.; Sun, Y. Solidification of additive-enhanced phase change materials in spherical enclosures with convective cooling. Appl. Therm. Eng. 2017, 111, $134-142$. [CrossRef]

32. Silalahi, A.O.; Sukmawati, N.; Sutjahja, I.M.; Kurnia, D.; Wonorahardjo, S. Thermophysical Parameters of Organic PCM Coconut Oil from T-History Method and Its Potential as Thermal Energy Storage in Indonesia. IOP Conf. Ser. Mater. Sci. Eng. 2017, 214, 012034. [CrossRef]

33. Tipvarakarnkoon, T.; Blochwitz, R.; Senge, B. Rheological properties and phase change behaviors of coconut fats and oils. Annu. Trans. Nordic Rheol. Soc. 2008, 16, 1-7.

34. Sharma, A.; Tyagi, V.V.; Chen, C.R.; Buddhi, D. Review on thermal energy storage with phase change materials and applications. Renew. Sustain. Energy Rev. 2009, 13, 318-345. [CrossRef]

35. Zalba, B.; Marín, J.M.; Cabeza, L.F.; Mehling, H. Review on thermal energy storage with phase change: Materials, heat transfer analysis and applications. Appl. Therm. Eng. 2003, 23, 251-283. [CrossRef]

36. Pomianowski, M.; Heiselberg, P.; Zhang, Y. Review of thermal energy storage technologies based on PCM application in buildings. Energy Build. 2013, 67, 56-69. [CrossRef]

37. Du, K.; Calautit K., J.; Wang, Z.; Wu, Y.; Liu, H. A review of the applications of phase change materials in cooling, heating and power generation in different temperature ranges. Appl. Energy 2018, 220, 242-273. [CrossRef]

38. Indartono, Y.S.; Suwono, A.; Pasek, A.D.; Mujahidin, D.; Rizal, I. Thermal characteristics evaluation of vegetables oil to be used as phase change material in air conditioning system. J. Tek. Mesin 2010, 12, 119-124. [CrossRef]

39. Irsyad, M.; Indartono, Y.S.; Suwono, A.; Pasek, A.D. Thermal characteristics of non-edible oils as phase change materials candidate to application of air conditioning chilled water system. IOP Conf. Ser. Mater. Sci. Eng. 2015, 88, 012051. [CrossRef]

40. Mettawee, E.S.; Ead, A.I. Energy saving in building with latent heat storage. Int. J. Therm. Environ. Eng. 2013, $5,21-30$. 
41. Boemeke, L.; Marcadenti, A.; Busnello, F.M.; Bertaso, C.; Gottschall, A. Effects of coconut oil on human health. Open J. Endocr. Metab. Dis. 2015, 5, 84-87. [CrossRef]

42. Kahwaji, S.; Johnson Michel, B.; Kheirabadi Ali, C.; Groulx, D.; Anne White, M. Fatty acids and related phase change materials for reliable thermal energy storage at moderate temperatures. Sol. Energy Mater. Sol. Cells 2017, 167, 109-120. [CrossRef]

43. Tansakul, A.; Chaisawang, P. Thermophysical properties of coconut milk. J. Food Eng. 2006, 73, $276-280$. [CrossRef]

44. Jayadas, N.H.; Nair, K.P.; Ajithkumar, G. Vegetable Oils as Base Oil for Industrial Lubricants-Evaluation Oxidative and Low Temperature Properties Using TGA, DTA and DSC. In Proceedings of the WTC2005 World Tribology Congress III, Washington, DC, USA, 12-16 September 2005.

45. Jayadas, N.H.; Nair, K.P. Coconut oil as base oil for industrial lubricants-Evaluation and modification of thermal, oxidative and low temperature properties. Tribol. Int. 2006, 39, 873-878. [CrossRef]

46. Moigradean, D.; Poiana, M.A.; Gogoasa, I. Quality characteristics and oxidative stability of coconut oil during storage. J. Agroaliment. Process. Technol. 2012, 18, 272-276.

47. Stokoe, W.N. The Rancidity of Coconut Oil Produced by Mould Action. Biochem. J. 1928, 22, 80-93. [CrossRef] [PubMed]

48. Okpokwasili, G.C.; Molokwu, C.N. Yeast and Mould Contaminants of Vegetable Oils. Bioresour. Technol. 1996, 57, 245-249. [CrossRef]

49. Henna Lu, F.S.; Tan, P.P. A Comparative study of storage stability in virgin coconut oil and extra virgin Olive oil upon thermal treatment. Int. Food Res. J. 2009, 16, 343-354.

50. Kothandaraman, C.P. Convection. In Fundamentals of Heat and Mass Transfer, 3rd ed.; New Age International Publishers: New Delhi, India, 2006; ISBN -13.

51. Richard, D.; Brien, O. Fats and Oils: Formulating and Processing for Applications; CRC Press LCC: Boca Raton, FL, USA, 2004.

52. Mehling, H.; Cabeza, L.F. Heat and Cold Storage with PCM, an up to Date Introduction into Basics and Applications; Springer: Berlin, Germany, 2008.

53. Paul, G.; Aleksandr, K.; Valeriy, M. Dew Point Evaporative Cooling: Technology Review and Fundamentals. ASHRAE Trans. 2011, 117, 111-118.

54. Lee, K.O.; Medina, M.A.; Sun, X. On the use of plug-and-play walls (PPW) for evaluating thermal enhancement technologies for building enclosures: Evaluation of a thin phase change material (PCM) layer. Energy Build. 2015, 86, 86-92. [CrossRef] 